\title{
POTENSI EKSTRAK ETANOL 70\% DAUN BINAHONG (Anredera cordifolia (Ten.) Steenis.) DAN EKTRAK ETANOL 96\% DAUN SIRIH HIJAU (Piper betle L.) TERHADAP BAKTERI Proteus mirabilis
}

\author{
Nur Patria Tjahjani ${ }^{1}$, Dyah Widhi Lestari ${ }^{2}$ \\ ${ }^{1,2}$ Staf Pengajar DIII Analis Farmasi, Akademi Farmasi 17 Agustus 1945 Semarang
}

Korespondensi Penulis:

$\begin{array}{ll}\text { Nama } & \text { Nur Patria Tjahjani } \\ \text { Alamat } & \text { : Prodi DIII Analis Farmasi Akademi Farmasi } 17 \text { Agustus } 1945 \text { Semarang } \\ & \text { Jl. Jendral Sudirman no. 350 Semarang } 50149 \\ \text { Nomor Telepon } & \text { (024) } 7608694 \\ \text { Email } & \text { : nurpatriacahyani@ gmail.com }\end{array}$

\begin{abstract}
Abstrak
Latar belakang : Daun binahong (Anredera cordifolia (Ten.) (Steenis) dan daun sirih hijau (Piper betle L.) sudah banyak dikenal masyarakat sebagai antiseptik alami untuk perawatan dan pencegahan berbagai macam penyakit yang diakibatkan virus dan bakteri seperti, infeksi saluran kemih yang diakibatkan oleh bakteri Proteus mirabilis. Daun binahong dan daun sirih hijau dapat sebagai antiseptik karena mempunyai kandungan zat aktif bakterisida.

Tujuan penelitian : Penelitian ini bertujuan untuk mengetahui perbedaan potensi antibakteri ekstrak etanol 70\% daun binahong (Anredera cordifolia (Ten.) Steenis) dan ekstrak etanol 96\% daun sirih hijau (Piper betle L.) terhadap bakteri Proteus mirabilis.

Metode : Metode yang digunakan pada penelitian ini adalah metode difusi cakram Kirby Bauer. Pada metode ini dilihat zona jernih yang dihasilkan dari disk kosong yang telah diberi ekstrak daun binahong dan ekstrak daun sirih hijau dengan konsetrasi 20\%, 40\%, 60\% dan 80\% untuk diinkubasi pada suhu dan waktu yang sesuai.

Hasil dan Kesimpulan : Dari penelitian yang dilakukan replikasi sebanyak 3 kali dapat disimpulkan ekstrak etanol 96\% daun sirih hijau (Piper betle L.) menunjukkan potensi antibakteri yang lebih kuat dalam menghambat pertumbuhan bakteri Proteus mirabilis dibandingkan dengan ekstrak etanol $70 \%$ daun binahong (Anredera cordifolia (Ten.) Steenis) dalam berbagai konsentrasi.
\end{abstract}

Kata kunci: Ekstrak daun binahong, ekstrak daun sirih hijau, Proteus mirabilis.

\section{Pendahuluan}

Penyakit infeksi merupakan penyakit yang banyak dialami masyarakat Indonesia. Bahkan tidak hanya orang dewasa yang dapat terkena infeksi, tetapi balita, anak-anak dan remaja dapat terkena infeksi. Salah satu penyebab infeksi adalah infeksi saluran kemih yang disebabkan oleh bakteri. Penyakit infeksi saat ini dapat ditanggulangi menggunakan obat modern yaitu antimikroba ${ }^{1}$. Penggunaan antimikroba termasuk antibiotik dan anti fungi yang tidak rasional telah menyebabkan banyak mikroba patogen beradaptasi dengan lingkungannya dan menjadi resisten 
terhadap obat tersebut ${ }^{2,3}$. Meningkatnya masalah resistensi menyebabkan kebutuhan akan obat antimikroba baru yang dapat mengatasi masalah resistensi juga meningkat, oleh karena itu pencarian antimikroba baru termasuk dari tanaman terus dilakukan ${ }^{4}$.

Salah satu tumbuhan yang dikenal luas oleh masyarakat adalah sirih dan binahong. Sirih merupakan tanaman yang telah banyak digunakan sebagai obat di Asia Tenggara. Sirih di Indonesia ada beberapa jenis, yang dibedakan berdasarkan bentuk daun, rasa dan aromanya, yaitu sirih hijau, sirih banda, sirih cengkih, sirih hitam dan sirih merah ${ }^{5,6}$. Tanaman binahong (Anredera cordifolia (Ten.) Steenis) adalah tanaman obat potensial yang dapat mengatasi berbagai jenis penyakit. Tanaman ini berasal dari dataran Cina dengan nama asalnya adalah Dheng shan chi, dikenal dengan sebutan Madeira Vine ${ }^{7}$.

Beberapa penelitian mengenai antimikroba alami yang efektif untuk melawan infeksi telah dilakukan. Salah satu tanaman yang telah diteliti adalah sirih hijau (Piper betle Linn). Daun sirih hijau telah dibuktikan mempunyai daya antibakteri ${ }^{8,9}$ dan daya antifungi ${ }^{10}$. Hasil penelitian terdahulu menunjukkan bahwa daun sirih hijau mengandung minyak atsiri yang terdiri dari betelfenol, kavikol, seskuiterpen, hidroksikavikol, kavibetol, estragol, eugenol, dan karvakrol. Minyak atsiri dan ekstraknya dapat melawan beberapa bakteri Gram positif dan Gram negatif ${ }^{6}$.

Binahong (Anredera cordifolia (Ten.) Steenis) merupakan tanaman obat yang tumbuh di dataran rendah atau dataran tinggi. Binahong memiliki akar, umbi, batang, bunga, daun yang mengandung senyawa aktif yaitu flavonoid, alkanoid, terpenoid dan saponin. Senyawa aktif flavonoid dapat berperan langsung sebagai antibiotik dengan mengganggu fungsi dari mikroorganisme seperti bakteri dan virus. Binahong juga mengandung antimikroba yang aktif sehingga dapat digunakan dalam mencegah pertumbuhan bakteri ${ }^{11}$.

Proteus mirabilis adalah salah satu bakteri yang dapat menyebabkan infeksi saluran kemih. Proteus mirabilis merupakan genus gram negatif, bergerak dengan flagel, tidak berspora, dan tidak berkapsul ${ }^{12}$. Proteus mirabilis salah satu penyebab terpenting infeksi saluran kemih, bakteri ini sulit diterapi dan dapat berakibat fatal serta dapat menimbulkan komplikasi antara lain pembentukan batu ginjal, vesika urinaria, bakterimia, dan sepsis ${ }^{12}$. Proteus mirabilis sering ditemukan di tanah dan di air serta merupakan flora normal pada saluran pencernaan manusia dan mamalia $^{12 .}$ Infeksi saluran kemih sering diderita oleh perempuan dibandingkan dengan laki-laki.

Penelitian terdahulu yang dilakukan oleh Syahrinastiti ${ }^{13}$, menunjukkan ekstrak daun sirih merah (Piper crocatum) memiliki efek daya hambat yang lebih baik terhadap pertumbuhan 
Escherichia coli dibandingkan ekstrak daun sirih hijau (Piper betle L.). Sedangkan penelitian yang dilakukan oleh Muhani ${ }^{14}$, menunjukkan ekstrak daun gaharu mampu menghambat pertumbuhan bakteri Staphylococcus aureus dan Proteus mirabilis. Penelitian ini bertujuan untuk mengetahui perbedaan potensi antibakteri ekstrak etanol 70\% daun binahong (Anredera cordifolia (Ten.) Steenis) dan ekstrak etanol 96\% daun sirih hijau (Piper betle L.) pada konsentrasi 20\%, 40\%, 60\%, dan 80\% terhadap bakteri Proteus mirabilis.

\section{Metode}

Jenis penelitian ini adalah eksperimental untuk melihat perbedaan masing-masing konsentrasi ekstrak etanol daun sirih hijau (Piper betle L.) dan ekstrak etanol daun binahong (Anredera cordifolia (Ten.) Steenis) terhadap pertumbuhan bakteri Proteus mirabilis, dengan desain penelitian Post test with control. Sampel yang digunakan pada penelitian ini berasal dari daun binahong dan daun sirih sebanyak 700 gram yang diambil dari desa Sumur Rejo Gunungpati, Semarang. Kontrol positif yang digunakan adalah paper disk antibiotik Ampicillin, sedangkan control negatif yang digunakan adalah larutan fisiologis $\mathrm{NaCl} 0,85 \%$. Variabel bebas dalam penelitian ini adalah ekstrak daun sirih dan ekstrak daun binahong dengan konsentrasi 20\%, 40\%, $60 \%$ dan $80 \%$. Sedangkan variabel terikatnya adalah pertumbuhan bakteri Proteus mirabilis pada media Muller Hinton Agar (MHA), diukur dengan berbagai diameter zona hambatan yang terbentuk.

\section{Alat dan Bahan}

Alat yang digunakan pada penelitian ini adalah peralatan gelas, penangas air, pemanas listrik, krustang, spatula, jarum ose, lampu spirtus, kasa steril, korek api, kertas disk cakram, oven, incubator dan otoklaf. Bahan yang digunakan adalah media Muller Hinton Agar (MHA), Media Heart Infusion Broth (HIB), ekstrak daun sirih hijau, ekstrak daun binahong, larutan fisiologis $\mathrm{NaCl}$ 0,85\%, aquadest steril, etanol 70\% dan 96\%, biakan Proteus mirabilis, paper disk Ampicillin.

\section{Prosedur Kerja}

\section{Tahap Persiapan}

Seluruh alat dan bahan yang akan digunakan disterilisasi di dalam autoclave selama 15 menit pada suhu sebesar $121^{\circ} \mathrm{C}$ setelah sebelumnya dicuci bersih, dikeringkan dan dibungkus 
dengan kertas atau alumunium foil. Daun binahong dan daun sirih hijau diperoleh dari tanaman di kebun di daerah Desa Sumurrejo, Gunungpati dikumpulkan dan dipisahkan antara daun dan ranting. Daun yang telah dipisahkan dari ranting kemudian diblender untuk menjadi serbuk kasar

\section{Pembuatan Ekstrak Daun Binahong dan Daun Sirih Hijau}

Metode yang digunakan dalam ekstraksi daun binahong (Anredera cordifolia (Ten.) Steenis) adalah metode maserasi ${ }^{15}$, dengan menggunakan pelarut etanol $70 \%$. Mula mula ditimbang 450 gram daun binahong, kemudian direndam dalam $3750 \mathrm{ml}$ pelarut, perbandingannya (10:75) selama 5 (lima) hari dalam botol gelap, diaduk kemudian ditutup. Penggojokan dilakukan minimal 3 kali dalam sehari, kemudian dilakukan penyaringan dengan corong dan kertas saring untuk memisahkan filtrat dari ampas. Filtrat diuapkan pelarutnya dengan menggunakan penangas air.

Metode yang digunakan dalam ekstraksi daun sirih (Piper betle L.) adalah metode maserasi. Didalam metode maserasi menggunakan pelarut etanol 96\% Mula-mula ditimbang 250 gram daun sirih hijau, kemudian direndam dalam $1875 \mathrm{ml}$ pelarut, dengan perbandingan (10:75) selama 5 (lima) hari dalam botol gelap, diaduk kemudian ditutup. Penggojokan dilakukan minimal 3 kali dalam sehari, kemudian dilakukan penyaringan dengan corong dan kertas saring untuk memisahkan filtrat dari ampas.Filtrat diuapkan pelarutnya dengan menggunakan penangas air.

\section{Pembuatan Variabel Konsentrasi Ekstrak Daun Binahong dan Daun Sirih Hijau.}

Larutan ekstrak daun binahong dan daun sirih hijau dibuat dengan konsentrasi masingmasing 20\%, 40\%, 60\%, dan 80\%. Kemudian diambil ekstrak daun sirih dan daun binahong sesuai dengan perhitungan konsentrasi. Ekstrak daun binahong dan daun sirih hijau diencerkan dengan menggunakan pelarut larutan fisiologis $\mathrm{NaCl}$ 0,85\% yang dimasukan ke dalam labu takar $10 \mathrm{ml}$. Blank paper disk dimasukkan ke dalam masing-masing ekstrak dan direndam selama 10 menit dalam cawan porselen.

Tabel 1. Perhitungan Ekstrak Daun Binahong 70\% dan Daun Sirih Hijau 96\% dalam berbagai variabel konsentrasi

\begin{tabular}{ccc}
\hline No & Konsentrasi & Perhitungan \\
\hline 1. & $20 \%$ & $\frac{20}{100} \times 10 \mathrm{ml}=2$ gram \\
\hline 2. & $40 \%$ & $\frac{40}{100} \times 10 \mathrm{ml}=4$ gram \\
\hline 3. & $60 \%$ & $\frac{60}{100} \times 10 \mathrm{ml}=6$ gram \\
\hline
\end{tabular}




\begin{tabular}{ccc}
\hline No & Konsentrasi & Perhitungan \\
\hline 4. & $80 \%$ & $\frac{80}{100} \times 10 \mathrm{ml}=8$ gram \\
\hline
\end{tabular}

\section{Pembuatan standart Mc Farland 0,5}

Standart jumlah kuman menggunakan cara Mc Farland, dengan cara mencampurkan larutan $\mathrm{H}_{2} \mathrm{SO}_{4} 1 \%$ dan larutan $\mathrm{BaCl}_{2} 1 \%$ ke dalam tabung reaksi steril dengan perbandingan larutan $0,05 \mathrm{ml} \mathrm{BaCl}_{2} 1 \%$ dan 9,9 $\mathrm{ml} \mathrm{H}_{2} \mathrm{SO}_{4} 1 \%$, lalu dihomogenkan. Suspensi $\mathrm{BaCl}_{2}$ yang terdapat dalam tabung diperkirakan sama dengan jumlah bakteri per mili liter yang terdapat dalam suspensi ${ }^{16}$.

\section{Pembuatan Suspensi Bakteri Proteus mirabilis}

Membuat larutan suspensi bakteri uji dengan cara menginokulasikan 1 (satu) ose biakan murni bakteri Proteus mirabilis ke dalam tabung reaksi yang berisi HIB, kemudian diinkubasi pada suhu $37^{\circ} \mathrm{C}$ selama 8 jam di dalam inkubator. Selanjutnya disamakan kekeruhannya dengan standart Mc Farland 0,5. Jika terlalu keruh dapat diencerkan dengan menggunakan HIB.

\section{Pembuatan media MHA (Mueller Hinton Agar)}

Mueller Hinton Agar Merck (38g/L) (casamino acid 17,5 gram, agar 17 gram,beef infution 300 gram ) ditimbang seberat 19 gram dan dimasukkan dalam Erlenmeyer dan dilarutkan dengan aquades $500 \mathrm{ml}$. Kemudian dipanaskan sampai larut sempurna dan tunggu sampai mendidih selama 1 menit sambil diaduk. Larutan media MHA disterilkan kedalam autoklaf dengan suhu 116 sampai $121^{\circ} \mathrm{C}$ selama 15 menit, kemudian dituangkan ke dalam cawan petri sebanyak $10-20 \mathrm{ml}$.

\section{Tahap Pengujian Uji Daya Hambat Dengan Metode Cakram Kirby Bauer.}

Media MHA disiapkan dan diberi tanda menjadi 6 (enam) bagian serta diberi etiket sesuai dengan variabel konsentrasi. Suspensi bakteri diambil menggunakan lidi kapas steril secara aseptis dan ditekan pada dinding tabung reaksi agar tidak terlalu tebal pada saat meratakan pada media MHA. Kemudian dilakukan isolasi pada media MHA dengan menggunakan lidi kapas steril dengan cara menyebarkan (swap) merata pada permukaan media Mueller Hinton Agar. Blank paper disk yang telah direndam diletakkan di dalam masing- masing konsentrasi ekstrak daun sirih hijau dan ekstrak daun binahong di atas media MHA dengan menggunakan pinset steril, beserta kontrol positif dan kontrol negatif sesuai dengan variabel konsentrasi pada etiket. Diatur jarak antar paper disk dengan kontrol positif, kontrol negative agar tidak terlalu berdekatan. Kemudian 
media diinkubasi ke dalam inkubator dan dilakukan pada suhu $37^{\circ} \mathrm{C}$ selama 24 jam.Diameter zona terang (clear zone) yang terbentuk diukur dengan menggunakan jangka sorong.

\section{Analisis data}

Data hasil penelitian efek ekstrak daun sirih hijau dan daun binahong pada Proteus mirabilis dianalisis dengan menggunakan program SPSS 20.0 untuk melihat ada perbedaan efektifitas yang bermakna dari masing-masing cakram uji yang mengandung kontrol negatif, berbagai konsentrasi ekstrak daun sirih hijau, daun binahong dan kontrol positif dalam menghambat pertumbuhan Proteus mirabilis. Data yang diperoleh disajikan dalam bentuk tabel dan diagram batang. Selanjutnya dilakukan uji statistika dengan uji T-test karena data berdistribusi tidak normal maka menggunakan uji non parametric yakni uji Mann-Whitney.

\section{Hasil}

Hasil pengujian tentang uji aktivitas ekstrak etanol $70 \%$ daun binahong (Anredera cordifolia (Ten.) Steenis.) dan esktrak etanol 96\% daun sirih hijau (Piper betle L.) terhadap pertumbuhan bakteri Proteus mirabilis yang telah ditumbuhkan dalam cawan petri menggunakan media Mueller Hinton Agar (MHA) ternyata menunjukkan kemampuan yang berbeda disetiap konsentrasi yang diberikan dapat dilihat pada tabel dibawah ini :

Tabel 2. Hasil penimbangan ekstrak dan hasil Rendemen Daun Binahong dan daun Sirih Hijau menggunakan pelarut etanol $70 \%$ dan etanol $96 \%$

\begin{tabular}{cccc}
\hline Nama Simplisia & Berat Simplisia & Berat Ekstrak & Nilai Randemen (\%) \\
\hline Daun Binahong & $450,0 \mathrm{~g}$ & 70,3513 & $15,6336 \%$ \\
\hline Daun Sirih Hijau & 250,09 & 26,8224 & $10,7289 \%$ \\
\hline
\end{tabular}

Tabel 3. Interpretasi Hasil Pengukuran Diameter Zona Hambat Ekstrak Etanol $70 \%$ Daun Binahong Terhadap Bakteri Proteus mirabilis

\begin{tabular}{ccc}
\hline Jenis Ekstrak & Konsentrasi (\%) & $\begin{array}{c}\text { Diameter Zona Hambat } \\
(\mathbf{m m})\end{array}$ \\
\hline Daun Binahong & $20 \%$ & 3,00 \\
\cline { 2 - 3 } & $40 \%$ & 4,00 \\
\cline { 2 - 3 } & $60 \%$ & 6,00 \\
\hline
\end{tabular}




\begin{tabular}{ccc}
\hline Jenis Ekstrak & Konsentrasi (\%) & $\begin{array}{c}\text { Diameter Zona Hambat } \\
(\mathbf{m m})\end{array}$ \\
\hline & $80 \%$ & 8,00 \\
\cline { 2 - 3 } & Kontrol + & 32,00 \\
\cline { 2 - 3 } & Kontrol - & 0 \\
\hline
\end{tabular}

Tabel 4. Interpretasi Hasil Pengukuran Diameter Zona Hambat Ekstrak Etanol 96\% daun Sirih Hijau Terhadap Bakteri Proteus mirabilis

\begin{tabular}{ccc}
\hline Jenis Ekstrak & Konsentrasi (\%) & $\begin{array}{c}\text { Diameter Zona Hambat } \\
(\mathbf{m m})\end{array}$ \\
\hline Daun Sirih Hijau & $20 \%$ & 6,00 \\
\cline { 2 - 3 } & $40 \%$ & 7,67 \\
\cline { 2 - 3 } & $60 \%$ & 10,00 \\
\cline { 2 - 3 } & $80 \%$ & 11,00 \\
\cline { 2 - 3 } & Kontrol + & 32,00 \\
\cline { 2 - 3 } & Kontrol - & 0 \\
\hline
\end{tabular}

HASIL PENELITIAN EKSTRAK ETANOL 70\% DAUN BINAHONG dan EKTRAK ETANOL 96\% DAUN SIRIH HIJAU

KONTROL (+) DAN KONTROL (-)
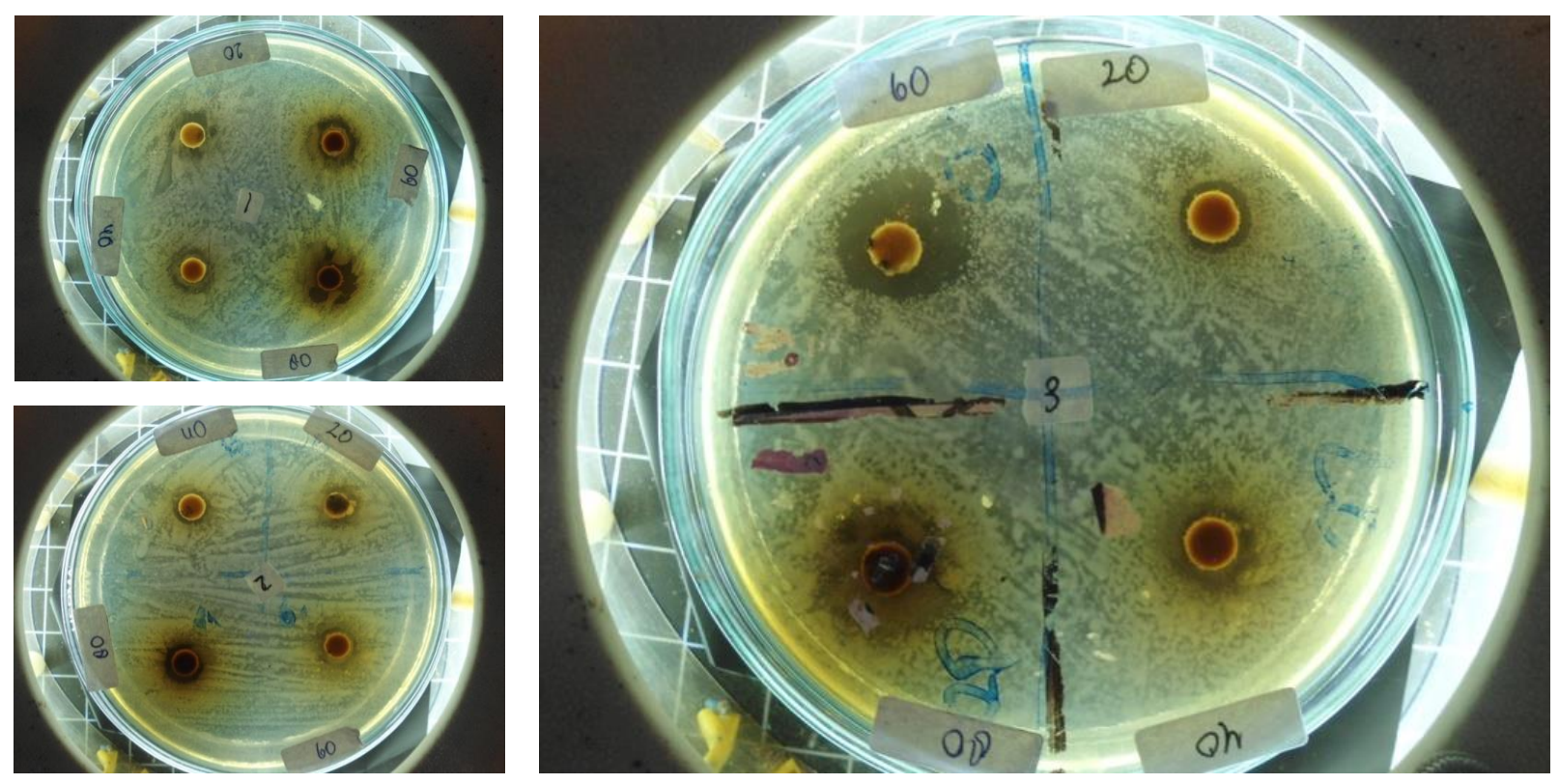

Gambar 1. Ekstrak Daun Sirih Hijau 

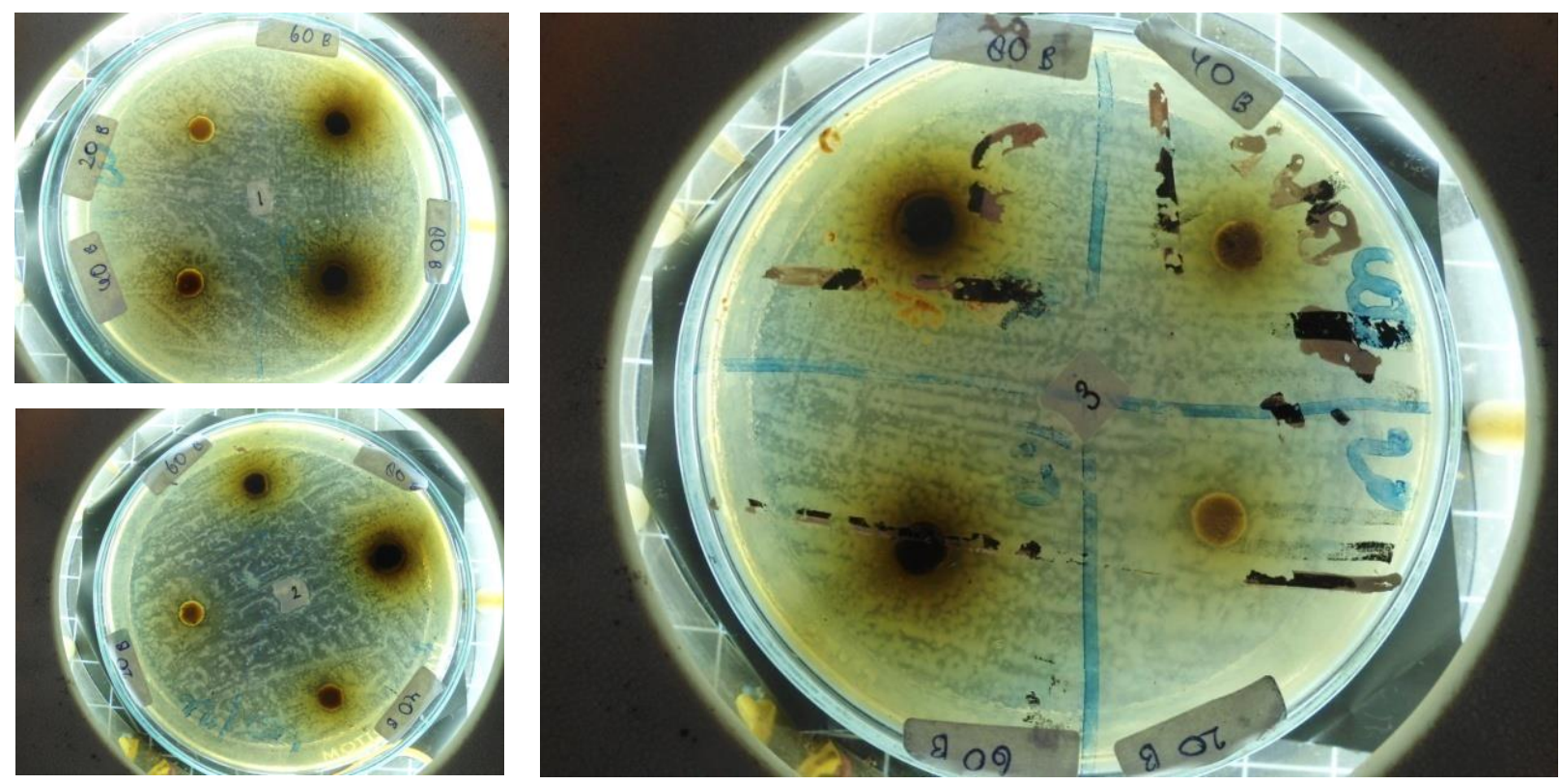

Gambar 2. Ekstrak Daun Binahong

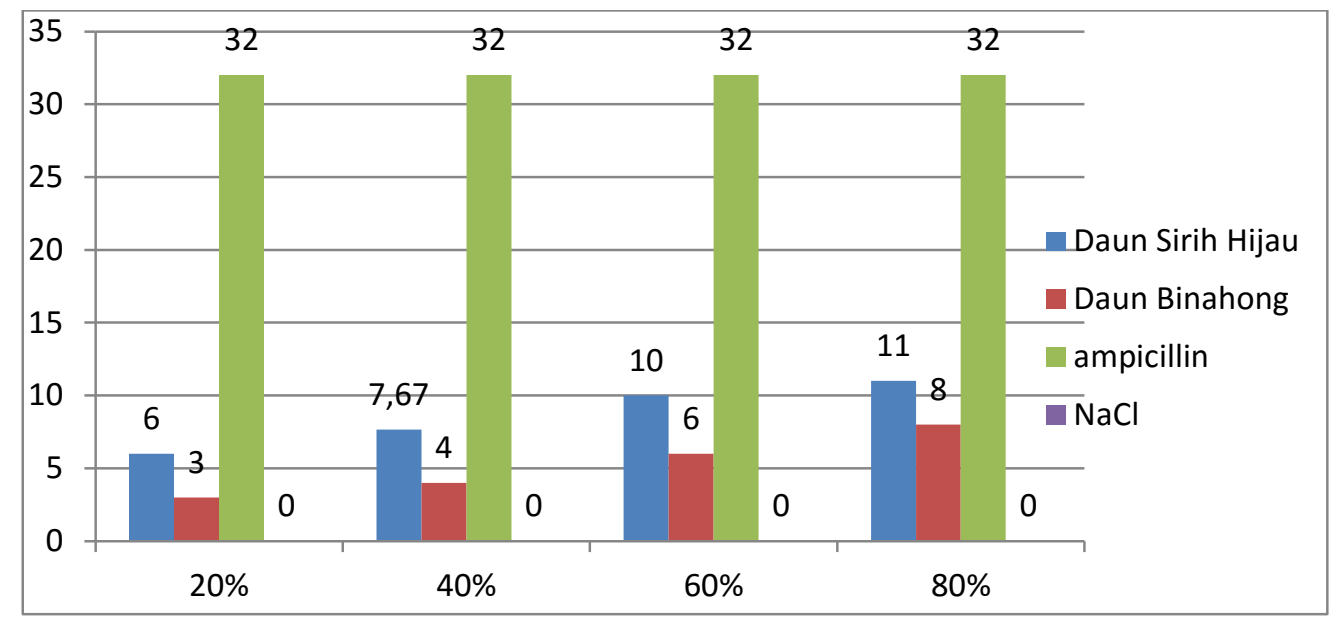

Gambar 3. Diagram Hasil Pengukuran Diameter Zona Hambat

Data penelitian berupa konsentrasi dan perbedaan daun terhadap pertumbuhan Proteus mirabilis dianalisis secara deskriptif dengan menggunakan nilai rata-rata, kemudian disajikan dengan tabel. Selanjutnya dianalisis statistik dan menunjukkan data tidak terdistribusi normal sehingga dilakukan uji non parametrik yaitu Mann-Whitney Test. Nilai signifikansi pada penelitian ini mengunakan variabel yang dianalisis pada nilai $p<0,05$.

Hasil uji Mann-Whitney Test pada ke empat kelompok konsentrasi ekstrak etanol daun binahong dan ekstrak etanol daun sirih hijau terhadap pertumbuhan bakteri Proteus mirabilis menunjukkan tidak adanya perbedaan zona hambat antara ekstrak etanol daun binahong dan 
ekstrak etanol daun sirih hijau terhadap pertumbuhan bakteri Proteus mirabilis dengan nilai signifikansi yang dianalisis yaitu $p=0,376>0,05$.

Tabel 5. Uji Zona Hambat Daun Binahong dan Daun Sirih Hijau - Mann-Whitney Test

\begin{tabular}{ccccccc}
\hline Jenis Daun & Bakteri Uji & \multicolumn{5}{c}{ Konsentrasi } \\
\hline & & $20 \%$ & $40 \%$ & $60 \%$ & $80 \%$ & \\
\hline Daun & Proteus & 3,00 & 4,00 & 6,00 & 8,00 & 0,376 \\
Binahong & mirabilis & & & & & \\
\hline $\begin{array}{c}\text { Daun Sirih } \\
\text { Hijau }\end{array}$ & Proteus & 6,00 & 7,67 & 10,00 & 11,00 & 0,376 \\
\hline
\end{tabular}

\section{Diskusi}

Hasil penelitian menggunakan metode difusi disk cakram menunjukkan ekstrak etanol 96\% daun sirih hijau (Piper betle L.) terbukti lebih kuat dalam menghambat pertumbuhan bakteri Proteus mirabilis dibandingkan dengan ekstrak etanol 70\% daun binahong (Anredera cordifolia (Ten.) Steenis) dalam berbagai konsentrasi yang dapat dilihat dalam Gambar 1. Diagram Hasil Pengukuran Diameter Zona Hambat.

Semakin besar konsentrasi maka semakin besar pula daya hambatnya terhadap pertumbuhan bakteri Proteus mirabilis. Ekstrak daun binahong dengan konsentrasi 20\%, 40\%, $60 \%$ dan $80 \%$ dengan hasil hambatan $3 \mathrm{~mm}, 4 \mathrm{~mm}, 6 \mathrm{~mm}, 8 \mathrm{~mm}$, sedangkan daun sirih hijau pada konsentrasi 20\%, 40\%, 60\% dan 80\% dengan hasil hambatan 6mm, 7,67 mm, $10 \mathrm{~mm}, 11 \mathrm{~mm}$ ${ }^{\text {menunjukkan }}{ }^{k}$ edua ekstrak daun tersebut memiliki kemampuan antibakteri namun ada perbedaan zona hambat yang dihasilkan pada konsentrasi yang sama.

Penelitian ini sejalan dengan penelitian yang dilakukan oleh Syahrinastiti ${ }^{13}$, yang membuktikan ekstrak daun sirih hijau (Piper betle L.) memiliki efek daya hambat terhadap pertumbuhan bakteri Escherichia coli. Daun sirih hijau (Piper betle L.) mengandung minyak atsiri dengan 30\% fenol dan beberapa derivatnya yang sebagian besar terdiri dari chavicol, paraallyphenol, turunan dari chavica betel, isomer eugenol allypyrocatechine, cineol methyl euganol dan caryophylen, kavikol, kavibekol, estragol, terpinen ${ }^{13}$. Zat bakteriostatik yang terdapat dalam daun sirih hijau minyak atsiri adalah betle phenol. Pada konsentrasi 0,1-1\% phenol bersifat bakteriostatik, sedangkan pada konsentrasi $1-2 \%$ phenol bersifat bakteriosida ${ }^{17}$. 
Penelitian yang dilakukan oleh Tjahjani dan Yusniawati ${ }^{18}$ membuktikan bahwa daun binahong mengandung metabolit sekunder bioaktif fenolik, saponin dan alkaloid. Penelitian yang dilakukan oleh Astuti ${ }^{19}$ didapatkan hasil bahwa ekstrak etanol daun binahong mengandung senyawa bioaktif fenol, flavonoid, saponin, terpenoid, steroid dan alkaloid. Ekstrak etanol daun binahong mempunyai peran penting sebagai antibiotika ${ }^{19}$. Ekstrak air sediaan celup daun binahong mengandung senyawa bioaktif yang berperan sebagai antioksidan, antimikroba, meredakan nyeri, stimulansia dan sekaligus dapat menurunkan kolesterol yang dapat menyehatkan jantung. Berbagai macam manfaat dari daun binahong inilah yang banyak menjadikan daun binahong untuk alternative pengobatan berbagai penyakit ${ }^{20}$.

Proteus mirabilis merupakan salah satu bakteri yang dapat menyebabkan infeksi saluran kemih $^{21}$. Bakteri ini dapat pula menyebabkan pneumonia dan juga prostatitis pada pria ${ }^{22}$. Proteus mirabilis menunjukkan jenis motilitas disebut sebagai swarming. Maryati et al. (2007), menjelaskan bahwa tebal tipisnya peptidoglikan akan mempengaruhi permeabilitas dinding sel bakteri $^{23}$. Bakteri Gram negatif mempunyai lapisan peptidoglikan yang tipis, terdiri dari 1-2 lapisan dan susunan dinding selnya tidak kompak sehingga memiliki permeabilitas yang cukup tinggi. Mekanisme inilah yang mengakibatkan ekstrak etanol daun binahong dan daun sirih hijau lebih mudah menembus dinding sel bakteri gram negatif yang bersifat bakteriostatik seperti flavonoid,alkanoid, terpenoid, saponin, dan minyak atsiri dengan 30\% fenol.

Flavonoid merupakan senyawa alam yang berpotensi sebagai antioksidan yang dapat menangkal radikal bebas yang berperan pada timbulnya penyakit degeneratif melalui mekanisme perusakan sistem imunitas tubuh, oksidasi lipid dan protein ${ }^{24}$. Daun binahong dan daun sirih hijau mengandung flavonoid yang dapat menghambat pertumbuhan bakteri gram negatif seperti Proteus mirabilis.

Senyawa aktif dalam daun binahong selain flavonoid juga mempunyai senyawa aktif saponin memiliki molekul yang dapat menarik air atau hidrofilik dan molekul yang dapat melarutkan lemak atau lipofilik sehingga dapat menurunkan tegangan permukaan sel yang akhirnya menyebabkan hancurnya bakteri ${ }^{25}$. Senyawa saponin seperti halnya senyawa fenol juga mempunyai aktivitas sebagai antioksidan ${ }^{20}$.

Daun sirih hijau mengandung senyawa minyak atsiri merupakan turunan dari senyawa fenol yang memiliki sifat antibakteri lima kali lipat dari senyawa fenol biasa. Mekanisme fenol sebagai agen antibakteri adalah sebagai toksin dalam protoplasma, merusak dan menembus 
dinding serta mengendapkan protein sel bakteri. Senyawa fenolik bermolekul besar mampu menginaktifkan enzim essensial di dalam sel bakteri meskipun dalam konsentrasi yang sangat rendah ${ }^{13}$.

Penelitian ini menggunakan metode ekstraksi sederhana yaitu maserasi menggunakan simplisia yang dibuat dengan cara perendaman, karena proses ini tidak menggunakan tahap pemanasan yang mengakibatkan kandungan zat aktif rusak, peralatan yang sederhana, biaya yang tidak terlalu mahal serta mudah dalam pengerjaanya. Prinsip ekstraksi didasarkan pada perpindahan masa komponen zat yang terlarut ke dalam pelarut sehingga terjadi perpindahan pada lapisan antarmuka dan berdifusi masuk ke dalam pelarut ${ }^{26}$. Pelarut yang digunakan adalah etanol $70 \%$ dan etanol $96 \%$, tujuan penggunaan etanol untuk mengeluarkan zat aktif yang ada dalam simplisia dan mencegah supaya simplisia tidak ditumbuhi bakteri lain pada saat proses perendaman.

Ekstrak yang diperoleh dipekatkan dengan waterbath sampai diperoleh ekstrak kental yang berwarna coklat kehijauan. Kemudian dilakukan perhitungan rendemen, sehingga diperoleh ratarata persen rendamen yaitu untuk daun binahong 15,6336 \% dan rata-rata persen rendemen daun sirih hijau yaitu $\quad 10,7289 \%$ yang dapat dilihat pada tabel 2 . Penentuan rendemen ini berfungsi untuk mengetahui kadar metabolit sekunder yang terbawa oleh pelarut namun tidak dapat menentukan jenis senyawa yang terbawa oleh pelarut ${ }^{27}$. Hasil rendemen dapat dipengaruhi oleh beberapa faktor antara lain varietas tanaman, umur tanaman, proses pemeliharaan tanaman, faktor lingkungan tempat tumbuh tanaman, juga proses panen serta proses pengolahan tanaman tersebut ${ }^{28}$.

Metode yang digunakan dalam penelitian ini adalah Difusi Disk cakram. Pada metode cakram kertas (Cara Kirby Bauer) digunakan suatu kertas cakram saring (paper disc) yang befungsi sebagai tempat menampung zat antimikroba. Disc diffusion test atau uji difusi disk dilakukan dengan mengukur diameter clear zone (zona bening yang tidak memperlihatkan adanya pertumbuhan bakteri yang terbentuk di sekeliling zat antimikroba pada masa inkubasi bakteri) yang merupakan petunjuk adanya respon penghambatan pertumbuhan bakteri oleh suatu senyawa antibakteri dalam ekstrak. Semakin besar zona hambatan yang terbentuk, maka semakin besar pula kemampuan aktivitas zat antimikroba.

Agen yang bekerja langsung membran plasma mikroorganisme, meningkatkan permeabilitas dan menyebabkan kebocoran sel intraselular. Membran plasma bersifat 
semipermiabel dan mengendalikan transport berbagai metabolit kedalam dan luar sel yang ada dalam daun binahong dan daun sirih hijau dimana pertumbuhan zona hambat yang terbentuk pada daun binahong dan sirih hijau dengan terlihat zona bening yang dapat menghambat pertumbuhan bakteri Proteus mirabilis.

Uji statistik menunjukkan data berdistribusi tidak normal dengan uji non parametrik yakni uji Man-Whitney Test $p=0,376$ yang berarti bahwa tidak ada perbedaan diameter zona hambat yang bermakna antara ekstrak etanol daun binahong dan ekstrak etanol daun sirih hijau. Daun binahong dan daun sirih mempunyai daya hambat yang sama kuatnya terhadap pertumbuhan bakteri Proteus mirabilis.

Hasil pengamatan secara langsung uji daya hambat ekstrak etanol daun binahong dan ekstrak etanol daun sirih hijau menunjukkan adanya hambatan yang berbeda yaitu zona hambat daun sirih lebih besar dibandingkan daun binahong tetapi keduanya dapat menghambat pertumbuhan bakteri Proteus mirabilis.

\section{Kesimpulan}

Ekstrak etanol 96\% daun sirih hijau (Piper betle L.) menunjukkan daya hambat yang lebih besar dalam menghambat pertumbuhan bakteri Proteus mirabilis dibandingkan dengan esktrak etanol 70\% daun binahong (Anredera cordifolia (Ten.) Steenis) dalam berbagai konsentrasi. Penelitian ini dapat dilanjutkan secara in vivo dengan menggunakan hewan coba untuk mengetahui efektivitas ekstrak etanol daun sirih dan ekstrak etanol daun binahong terhadap pertumbuhan bakteri Proteus mirabilis.

\section{Daftar Pustaka}

1. Tjay, Tan Hoan, Rahardja, K., Obat - Obat Penting, $7^{\text {th }}$ Ed, PT. Elex Media Komputindo, Jakarta, 2015

2. Wowling, Chalvy., Goenawi, Lily Ranti., Citraningtyas, Gayatri., Pengaruh penyuluhan Penggunaan Antibiotika Terhadap Tingkat Pengetahuan Masyarakat di kota Manado, Pharmacon Jurnal Ilmiah Farmasi-UNSRAT, Vol 2. No.3,2013, h.24-28.

3. Humaida, Rifka., Strategy to Handle resistance of Antibiotics, J.Majority, Vol.3 No.7, 2014.h.113-120.

4. Ervizal, Dasar - Dasar Mikroorganisme, Universitas Indonesia Press, Jakarta, 2011. 
5. Moeljanto, R.D., Mulyono., Khasiat dan Manfaat Daun Sirih, Obat Mujarab dari Masa ke masa. Agromedia Pustaka, Yogyakarta, 2003, h. 7-11.

6. Sudewo, B., Basmi Penyakit dengan Sirih Merah, PT Agromedia Pusat, Jakarta.2010, pp. 3747.

7. Feri, M., Binahong (Anredera cordifolia (Ten.) Steenis) Sebagai Obat. Jurnal Warta Penelitian dan Pengembangan Tanaman Industri. Volume 15 Nomor 1:3., 2009.

8. Bustanussalam., Apriasi, Devi., Suhardi Eka., Jaenudin, Dadang., Efektivitas Antibakteri Ekstrak Daun Sirih (Piper betle Linn) terhadap Staphylococcus aureus ATCC25923, Fitofarmaka, Vol.5 No.2, 2015, h.58-64.

9. Jayalaksmi B., Raveesha , KA., Murali, M. and Amrutesh, K.N., Phytochemical, antibacterial and antioxidants studies on leaf extracts of Piper betle L., International Journal of Pharmaceutical Sciences, Volume 7, Issue 10, 2015, p.23-29.

10. Setiari, Ni Made Nita., Ristiati, Ni Putu., Warpala, I Wayan Sukra., Aktivitas Anti Fungi Kombinasi Ekstrak Daun Sirih (Piper betle) dan Ekstrak Kulit Buah Jeruk (Citrus reticula) Untuk Menghambat Pertumbuhan Candida albicans, Jurnal Pendidikan Biologi Undiksha, vol 6. No. 2 , 2019, h. 72-82.

11. Rimporok, S., Kepel, B. J. and Siagian, K. V., Uji efektivitas ekstrak daun binahong ( Anredera Cordifolia Steenis ) terhadap pertumbuhan Streptococcus mutans secara in vitro, Jurnal Ilmiah Farmasi, 4(4), 2015, pp. 15-21.

12. Mufida, D. C., Sumarno and Santoso, S., Identifikasi Protein Adhesi Pili Proteus Mirabilis P355 dan Protein Reseptor pada Vesika Urinaria Kelinci, 2010, 1(1), pp. 3-8.

13. Syahrinastiti, TA. Djamal, A. Irawati, L. Perbedaan Daya Hambat Ekstrak daun Sirih Hijau (Piper betle L) dan Daun Sirih Merah (Piper crocatum Ruiz \& Pav) terhadap Pertumbuhan Escherichia coli. Jurnal Kesehatan Andalas. Volume 4, No2. 2015, DOI : https://doi.org/10.25077/jka.v4i2.265.

14. Muhani, M. Sari, Rafika. Fajriaty, Inarah. Uji Aktivitas Antibakteri Ekstrak Etanol Daun Gaharu (Aquilaria microcarpa Baill.) Terhadap Bakteri Staphylococcus aureus dan Proteus mirabilis, Vol. 4, Nomor 3. 2017, DOI : 10.7454/psr.v4i3.3756.

15. Departemen Kesehatan RI. Parameter Standard Umum Ekstrak Tumbuhan Obat. Direktorat Jendral Pengawasan Obat dan Makanan.Jakarta, 2000.

16. Suriawiria, Mikrobiologi Dasar, Pupus Sinar Sinanti, Jakarta, 2005.

17. Fuadi S. Efektivitas Ekstrak Daun Sirih Hijau (Piper betle L.) terhadap pertumbuhan bakteri Streptococcuspyogenes in vitro [skripsi]. Jakarta: Universitas Islam Negeri Syarif Hidayatullah;Hidayatullah; 2014. 
18. Tjahjani, Nur Patria., Yusniawati., Gambaran Senyawa Bioaktif dalam Sediaan Celup Bihahong (AnrederaCordifolia (Ten) Steenis). Jurnal Farmasi Stikes Cendekia Utama, Kudus. Vol 1 no 1, 2017.

19. Astuti, SM., Mimi, SAM., Retno ,ABM., Awalludin, R., A Determination of Saponin Compound from Anredera cordifolia (Ten.)Steenis ( Binahong) topotential treatment for several diseases. Journal Agricultural Science, CanadianCenter of Science and Education. Vol 3 No. 4, December 2011.

20. Manoi, F., Binahong (Anredera cordifolia) Sebagai Obat. Bulletin Warta Volume 15, Number 1, April. Penelitian dan Pengembangan Tanaman IndustriBadan Penelitian dan pengembangan Pertanian Pusat Penelitian dan Pengembangan Perkebunan Indonesia.

21. Simatupang, M., Enterobacteriaceae (online), diakses 28 Mei 2021.

22. Kurniawan, A, Proteus mirabilis, (online), (http://www.scribd.com/doc/49762885/proteusmirabilis, diakses tanggal 18 Mei 2021). Lindquist.

23. Maryati, Fauzia, R. S., \& Rahayu, T., Uji Aktivitas Antibakteri Minyak Atsiri Daun Kemangi (Ocimum basilicum L.) terhadap Staphylococcus aureus dan Escherichia coli, Jurnal Penelitian Sains dan Teknologi, 2007, 8 (1), 30-38.

24. Rais, I. R., Isolasi dan penentuan kadar flavonoid ekstrak etanolik herba sambiloto (Andrographis paniculata (burm. F.) Ness). Pharmaciana, 2015, pp 100:106.

25. Ji YS., Lestari, N.D., Rinanda, T., Uji Aktivitas Antibakteri Ekstrak Etanol30\% dan 96\% kelopak bunga rosella ( Hibiscus sabdariffa) terhadap bakteri Streptococcus pyogenes secara in vitro. Jurnal Kedokteran Syiah Kuala, 2012., 12(1), 31-36

26. Harborne, J.B., Metode Fitokimia Penuntun Cara modern Menganalisis Tumbuhan. Terjemahan: Kosasih P, SoediroIwang, Bandung, 1996, ITB; 6-17

27. Ahmad, A.R., Juwita, J., Ratulangi, S.A.D. dan Malik, A., Penetapan Kadar Fenolik Dan Flavonoid Total Ekstrak Metanol Buah Dan Daun Patikala (Etlingera Elatior (Jack) Rm Sm) Menggunakan Spektrofotometri Uv- Vis. Pharmaceutical Sciences And Research (Psr), 2016, 2(1), Pp.1-10.

28. Ayunda., Aktivitas antioksidan ekstrak etanol daun serai (Cymbopogon citratus) dan potensinya sebagai pencegah oksidasi lipid (Skripsi). Institut Pertanian Bogor, Bogor. Banjarnahor, 2014 